\title{
From a policy bank to a crowding-in bank: The development of the European Investment Bank in the last ten years, as seen through its business model
}

\author{
Helen Kavvadia \\ University of Luxembourg
}

\section{Abstract}

The European Investment Bank (EIB), the primary financial arm of the European Union (EU) has become of central interest in the last ten years. The EIB has been increasingly solicited by the EU to bolster the European economy during the global crisis and support its recovery thereafter. Calls have recently been voiced for the EIB to contribute to the European Green Deal and the post-pandemic economic stimulus. This paper studies the EIB's role in the European economy through its business model in the period from 2009-2019. The paper's prime objective is to investigate what enabled the EIB to act in a countercyclical mode and how the EIB met the new economy needs in this turbulent environment.

Keywords: Business Model, European Investment Bank (EIB), Institutional Governance

Paper type: Research article

Received: 17. 6. 2020.

Accepted: 2. 7. 2020.

DOI: $10.2478 / \mathrm{crdj}-2021-0003$

\section{Introduction}

The European Investment Bank (EIB), the primary financial arm of the European Union (EU) took centre stage following the economic crisis in 2008. In the ten-year period of 20092019 , the EIB has been called upon to act in a countercyclical mode by increasing its lending amid the economic crisis and subsequently promote the EU's smart, sustainable and inclusive growth. More recently, the EIB has been solicited to bolster the EU's Green Deal announced in late 2019 and redress the consequences of the pandemic in 2020.

In this context, academic interest in the EIB has recently increased, although it does not match the bank's economic and political clout. Academic literature focuses mainly on the EIB's financing activity (Liebe \& Howarth 2019; Clifton et al., 2018; Anghel et al. 2016; Clifton et al. 2014; Pistoia 2014; Marzinotto 2011; Fedele et al. 2010). This paper aims to complement existing scholarly work by examining the EIB as an organisation in the last ten years. It will address the following questions: What enabled the EIB to act in a countercyclical mode? What enabled the EIB to meet the new needs in this turbulent environment? 
Following a Popperian approach, this paper studies the EIB as an organisation for a period in which its policies and practices constitute trial solutions to prevailing economic and social problems. To answer the research questions, the paper examines the EIB's business model. An organisation's business model describes how it creates and delivers value, providing a unique vantage point from which to observe the organisation (Calvante et al. 2011; Johnson et al. 2008; Osterwalder 2004; Zott et al. 2011). A business model contains strategy and activity parameters, and it unveils a business's structure and processes, so it can be used to plan an organisation's future but also to study its past and present. Although the EIB's officials have made frequent reference to its business model, these have been short verbal descriptions connected with the bank's triple-A credit rating (EIB 2010; Szymczak 2010; EIB 2011; Camdessus, M. 2010, p. 19). Given the implicit link with EIB's rating, the bank's recent references have been diversified, coining the name "EIB's financial model" (EIB 2019b, p. 18). The EIB's business model has never been available in the public domain. Nevertheless, this paper presents the EIB's business model, crafted based on a hybrid archetype devised by the author to match the bank's dual nature as an EU body and a bank. Based on an existing archetypal model (Johnson et al. 2008) and reflecting the affinity diagram of business models' components (Schafer et al. 2005), this hybrid model consists of four primary interlocking elements that reflect the institutional side and the banking side of the EIB: a) strategic choices, which describe the core logic; b) value capture, which refers to the capabilities and competencies that secure the resources needed for the organisation's viability; c) value creation, which concerns how the organisation delivers its value proposition to the client; and d) value network, which pertains to the internal and external support web of staff, stakeholders, peers, and suppliers. The EIB's institutional side consists primarily of its strategic choices and, to a lesser extent, its value network, whereas the value creation and value capture elements reflect the EIB's banking side. This generic hybrid model has been tailored to the EIB by filling in its elements with the EIB's business fundamentals. As an EU body, the EIB's fundamentals are contained in the bank's statute (EIB 1999; OJEU 2016) and are in the public domain, as they form an integral part of the EU's treaties (Edward \& Lane 2013).

The review of the EIB's statutes overtime reveals that only two of them resulted in business model revisions (Kavvadia 2018). These revisions, which took place in 1999 and 2010, were driven to a great extent by a mixture of European policy and market developments, reflecting the introduction of the Euro and the difficult economic environment in the EU before and during the global economic crisis. The November 2019 announcement of the EIB's pivot to become the first international climate bank and its statutory modification following the United Kingdom's departure from the EU in March 2020 are beyond the scope of the present analysis. This paper focuses on the EIB's 2010 model, which was applied until the end of the ten-year period under review. Benchmarking the model by the EIB's annual performance, the analysis shows that the model is well conceived and has proven robust and flexible, allowing for the bank's inorganic and organic growth. Inorganic growth means growth originating from external political calls for activity, which the EIB has fulfilled, acting as a policy-taker. Organic growth refers to the EIB's augmented activity resulting from the extension of its normal business and to cases when the EIB acts as a policy-maker (Mertens \& Thiemann 2019) or policy entrepreneur (Liebe \& Howarth 2019), promoting policies and products that suit its operational plans. The bank was consequently able not only to fulfil its remit in support of European policies but also to boost its own organisational objectives.

This paper adds to existing work and contributes to scientific research by studying the EIB to improve understanding of its function as an organisation.

The paper is organised as follows: the next section presents the EIB's business model for the ten-year period of concern, analyses the model and attempts to explain how it bolstered the bank's activity over this turbulent period. The conclusion briefly summarises the paper's major findings. 


\section{Mastering the turbulent crisis environment: An "all-weather" business model?}

The business model under study has been in force since 2010, coinciding with the spread of the economic crisis in the EU. It was crafted, however, based on previous deliberations at the EU's and EIB's top levels. This model is a consolidation and extension of the EIB's 1999 model - the model's first revision since the bank's establishment in 1957-which is presented in Figure 1, with the relevant changes to the 2010 model underlined in the diagram in Figure 2. These changes were introduced gradually, reflecting Lindblom's incrementalism (Lindblom 1959). Characterised by a remarkable flexibility in interpreting European policy-makers' objectives, the EIB's 1999 business model enabled the bank to develop from mono-focus activity, such as regional development and, later, market-making or investment promotion (Clifton et al. 2014, 2018), to multi-foci activity for smart, sustainable and inclusive growth. The 1999 revision of the business model was deemed necessary because of the cataclysmic changes leading up to the Euro's introduction concerning both investment supply and demand under the prevailing financial conditions. The enlarged, liquid single-Euro capital markets bred fierce competition among issuers in terms of interest rates. On the demand side, the Maastricht criteria restricted public financing of investments and curtailed lending demand. Against this backdrop and amid a reshaping of economic governance, the EIB had to remain useful to the EU, which was seeking growth against all odds. The EIB faced some challenges: i) high lending volumes to publicly financed infrastructure projects could no longer be expected, and ii) a turn to increased private lending was challenging, as EIB's fine interest rates were no longer attractive to private borrowers, who could tap the vast, liquid Euro capital markets, while the single currency dissipated the EIB's ability to lower rates through arbitrage.

The global economic crisis created a different situation. On the supply side, existing liquidity sought good investment prospects in capital markets, and EIB's triple-A was exceptionally attractive amid several sovereign downgrades. On the demand side, however, investment plans were arrested, as public finance was devastated by the sovereign debt crisis and private finance was put on hold due to prevailing uncertainties and consumption collapse. The EIB's 2010 business model revision therefore aimed predominantly to redress demand difficulties. EU policy decisions, partly stemming also from the EIB's activism (Liebe \& Howarth 2019), resulted in change to the ElB's strategic choices, which triggered concomitant modifications in all four elements of its business model. However, this study's analysis shows that these changes were carried out primarily in the value capture and the value network elements of the bank's business model.

To address private sector needs, the EIB's offering remained focused on lending but pivoted to increased leverage, achieving higher investments with the same amount of funding through so-called special activities. These special activities included risk capital and equity participation and structured finance. To increase its leverage-in other words, to obtain a higher multiplier for its lending and hence a greater impact on new investment creation through these special activities-the EIB focused on: i) blending its own funds with EU Commission resources; ii) upgrading the role of the European Investment Fund (EIF), the EIB's subsidiary, by distinguishing more clearly between venture-capital funding and lending, respectively, aiming to increase intra-group coherence, complementarity and efficiency; iii) developing new financial roles, such as bond purchaser and underwriter; and iv) institutionalising its long-claimed catalyst role, by monetizing its human resources by providing advisory services.

Paired mainly with the European Commission, the EIB's advisory services were offered through the Joint Initiatives and, later, the European Fund for Strategic Investments (EFSI) as part of the "Juncker Plan." These advisory services also extended its public-private partnerships (PPPs) expertise into a further consulting area (Liebe \& Howarth 2019). The EIB's activism in this area had already begun under its 1999 business model, resulting in 
the creation of the European PPP Expertise Centre (EPEC) in 2008. EPEC was further developed under the bank's 2010 model as a way to continue the ElB's funding of infrastructure projects despite the public sector retreat. Building on its value network and its strength as a catalyst for large infrastructure financing, the EIB recently described itself as a "crowding-in bank" (EIB 2019b, p. 12). This term implies that the EIB's due-diligence process provides a quality shield to projects, paving the way for commercial banks and other investors to crowd-in. Unlike commercial banks, the ElB's project appraisals go beyond financial risk to include market, economic, environmental and technological risks.

In its catalyst role, the EIB also cultivates synergies with other financiers. Since 1999, the EIB has sought to cooperate with other Multilateral Development Banks (MDBs), as shown by the increasing number of agreements in the form of Memoranda of Understanding. These memoranda have resulted in mutual benefits including i) enrichment of their client base and project pipelines by cross-sharing projects; ii) denting operating costs by sharing project appraisal tasks; iii) paring down project and borrower/guarantor risks through risksharing, resulting in improved asset quality; and iv) affirmation of their relevance by demonstrating an efficient use of public funding through cooperation.

The EIB also scaled up its partnership with commercial banks and national promotional agencies (NPAs). The EIB has striven to cooperate with national banking systems since its establishment. Even if it filled market failures, supra-national public funding could not be easily justified if it competed with commercial banks, which are valuable national interests. This is especially the case because organisations seek parallel market opportunities when filling market failures.

As the Bank pointed out in its first Annual Report in 1958, by creating not another fund, but a bank, the six member states: set aside more direct financial intervention methods which no doubt would not in the long run have enabled adequate resources to be raised. They particularly wished the promotion of investments . . . to be carried out by existing banking houses ... That is, they wished to utilise the commercial world banking system, with the EIB providing 'an additional source of financing which might prove decisive' in creating or furthering projects they wanted realised. (Lewenhak 1982, p. 23)

Since its conception, the EIB has been a complementary source of finance with its funding limited to a maximum of $50 \%$, or in exceptional cases $75 \%$, of the total project cost, allowing other financiers to take part in its deals. Cooperation with the banking network has always been a project purveying channel for the EIB, especially for reaching small- and mediumsized enterprises (SMEs), which historically represent about $30 \%$ of EIB annual lending, and other direct or indirect loans, mainly with a commercial bank as the intermediary borrower. The EIB's cooperation with the banking system not only increases the lending activity of all actors but also mitigates their risks through aggregation and sharing. The EIB also cooperates with commercial banks in guarantee operations, guaranteeing their loans or vice versa, which historically represents about $30 \%$ of all EIB guarantees. The banking sector, an important partner of the EIB on its borrowing side, has benefited from commissions and fees on the EIB's vast emission programmes while often using the EIB's SMEs financing lines-known as global loans-as treasury funding. The EIB's partnership with commercial banks has enabled it to function for about 40 years with no active client solicitation in its business model until 1999. Customer and investor relations were further strengthened in the 2010 model through an increased number of direct contacts in the form of road shows, fora, national and regional conferences, global relations management (GRM) and a new worldwide office network, which includes about 50 regional offices from all continents in the last 10 years.

The objectives added to the EIB's 1999 model, such as human capital and innovation, allowed the bank to refocus from a limited number of specific policy foci, notably regional development and market-making activities (Clifton et al. 2014), to multiple foci, covering 
"smart, sustainable and inclusive growth". These objectives were applied flexibly to match the ever-evolving European requirements, in support of the Lisbon Agenda in 2000, the European Action for Growth in 2003 and the Europe 2020 Initiative in 2009, which led to the EIB's consequent endorsement by successive EU Councils. Despite its success, the EIB's 1999 business model had to be revised within ten years to adapt to the pre-crisis and global crisis context characterised by sluggish investment despite abundant liquidity. The EIB's 2010 model aimed to channel inactive liquidity into investments by enabling the EIB to carry higher risks, thereby further increasing the bank's competitiveness and relevance. The 2010 model went well beyond a quantitative increase of EIB lending volumes, which would have had unspectacular results, considering the EIB's lending from 2010-2017 represented only $2.5 \%$ of the EU's GDP and $10 \%$ of the EU's gross fixed capital formation (GFCF) . The model's revisions therefore targeted the qualitative turn of EIB lending, prioritising new areas for promoting smart and inclusive growth, such as human capital and innovation. By their nature, however, investments in these areas bear greater risks and require adapted finance products. The increased risk-taking and risk-sharing products the EIB had started to test and implement under its 1999 business model came to the fore to be further developed, strengthened and complemented with new ones to achieve increased leverage. Unlike several of its peer MDBs, the EIB's resultant scaled-up risk appetite and leverage carried low intrinsic risk, allowing the bank to maintain its top-notch triple-A rating. The EIB's low intrinsic risk is due to the value capture element of its business model, which has demonstrated several key strengths that characterise the EIB and differentiate it from its peers: a) strong shareholders' support, as evidenced by successive capital increases and the resulting metrics (EIB 2017; EIB 2016); b) strained yet satisfactory capital adequacy, thanks to its strong asset quality ; C) low-risk operating environment, as the EIB has provided about $90 \%$ of the lending in the EU's highly developed shareholder countries ; d) diversified loan portfolio in terms of geographical, sectoral and counterparty-type; e) adequate liquidity with a twelve-month buffer, strengthened further by the bank's access to the European Central Bank (ECB)'s liquidity facilities, which is almost unique among peer MDBs ; f) prudent risk management enhanced by the EIB's preferred creditor status (PCS) $(E I B, 2016)$, which is also rare among peer MDBs;g) high asset quality, due to the highquality borrowers who approach the EIB and the bank's due-diligence and guarantee requirements; $h$ ) externalisation of operations bearing the highest risk to the EU or member states-a unique feature among its peers, giving the EIB an advantage over other MDBs (Kavvadia, 2020)—which means it enjoys guarantees for its portfolio outside the EU and within the EU for high-risk projects.

The EIB's qualitative turn to new areas of priority was supplemented by a further improvement to its business model in 2010. This model institutionalised the blending of EU grants with EIB loans for better, more efficient and effective coordination of European funding for investment projects. The EIB has always cooperated and coordinated with the Commission, its sister institution, in terms of policy, financial support of European priority areas and EU funding channelled through the EIB under the mandate of prime policy areas. Examples within the EU include the New Community Instrument (NIC), topical natural catastrophe interventions and, more recently, the EFSI and most EIB operations outside the EU. This EIB feature of cooperating with the Commission is unique among MDBs and has been further extended in the bank's 2010 model to blend EIB resources at market rates with the Commission's grants under the Structural Funds, resulting in reduced aggregate funding costs. Cost reductions being paid upfront, the cost reductions that are achieved through injecting grants into projects' finance plans have better effects on investments than interest-rate subsidies; these cost reductions provide front-loaded relief during the initial phases of a project's realisation, when start-up costs are high and cash flow rarely reaches target levels, while their present net value is higher. With such cost reductions, EIB's lending terms became even more competitive. These cost reductions were attractive to project promoters, allowing the EIB to maintain its market share amid the fierce competition of the 
Euro euphoria period, and they enabled the EIB's countercyclical intervention during the crisis years.

Beyond the funding blend, the closer cooperation between the EIB and the Commission was also institutionalised through a number of Joint Initiatives concerning SMEs, urban renewal and technical assistance to infrastructure projects. These initiatives benefited the EIB by enlarging its customer base, reaching 530 new advisory assignments in 2018 (EIB, 2019c:3), while increasing its income from advisory services fees. The Joint Initiatives also enriched the Commission's technical skills. Additionally, the qualitative improvements foreseen in the 2010 model triggered concrete benefits for the European investment scene by i) buffeting the EIB's multiplier effect for more impactful lending; ii) scaling up investment through cross-sharing projects among MDBs; and iii) developing new investment proposals through advisory services, which assisted in the design and setup of bankable projects. Furthermore, these three qualitative improvements constituted the springboard for EIB's increased activity in support of the EU's counter-crisis efforts for recovery and growth. The EIB's contribution to these EU efforts has not been limited to its normal activity. It has received an additional and considerable thrust through the EFSI, which was created in the framework of the Juncker Investment Plan in 2015. Beyond higher lending volumes, the EFSI focused on changing the qualitative profile of projects to be financed through increased risk-taking, "eyeing" in particular projects in "strategic infrastructure, education, RDI, renewable energy and resource efficiency, as well as support for SMEs and Midcaps" (EIB 2016, p. 1). Carrying a higher-than-average credit risk embedded in the EIB's portfolio , loans under the EFSI benefit from the EU guarantee representing $25 \%$ of the total (for bolstering the EIB's value creation element) while EFSI equity and mezzanine instruments were also guaranteed by the EU.

This type of EIB activity, with part of the risk exported to the EU, will continue because the bank is also expected to play an important role in InvestEU (EIB,2019a), the Juncker Plan's successor. InvestEU will be based on a 38 billion EUR guarantee from the EU budget, with the aim of mobilising 650 billion EUR of investment to allow the EU to remain "social, green and competitive" (EIB, 2019a). Entrusting the implementation of the Juncker Plan and its forthcoming successor InvestEU to the EIB confirmed anew the bank's European mandate, which constitutes an integral part of the bank's future development, as mentioned by its president: "InvestEU, from our perspective-from the perspective of investment and growth-is about transforming EFSI into a long-term, robust and financially sustainable tool to support EU policy delivery, notably in those key areas of innovation, climate and cohesion that I mentioned a minute ago" (EIB 2019b, p. 11). Nevertheless, InvestEU dethrones the EIB from its privileged and long-held position as the sole counterparty of the EU's major financing initiatives, which places the bank at par with other financial organisations, such as the National Promotional Banks (NPBs). Still, by guaranteeing project risks, InvestEU will allow the bank to continue playing an important role-albeit smaller, entrusting the EIB with only $75 \%$ of the funds-in economic sectors of prime European importance, such as innovation and climate enhancement. However, InvestEU is intended to demonstrate higher efficiency and effectiveness than the Juncker Plan by introducing competition among the financial actors, including the EIB and NPBs, while spreading risk more widely among EIB and NPBs. InvestEU has therefore been conceived with a higher multiplier of 17 than that of the original EFSlat 15. Through higher leveraging, EU funding is expected to have an increased impact and outturn investment amounts. While it is required to move into riskier projects, the EIB continues to be soothed by EU guarantees for prudently implementing such requested activities. As riskier loans consume larger parts of capitalisation , the 2012 capital increase and the 2020 capital replenishment have bolstered the effectiveness and resilience of the EIB's value capture element. Conversely, if these riskier loans are provided to successful investment schemes, they offer high returns; the EIB has therefore turned 
from a "non-profit-making" (EIB, 1988:1) to a "non-profit-maximising" (EIB, 2011:41) organisation.

To improve the leverage of the combined EU budget and EIB resources, the bank's 2010 business model institutionalised a three-pillar activity in its strategic choices element, namely lending, blending and advising. This three-pillar structure has allowed the EIB not only to develop multi-foci activity but also to devise and test, in parallel and under one roof, five different types of business and banking: a) wholesale banking for SME financing via partner banks; b) development banking for financing outside the Union; c) for-profit banking for risk-taking and -sharing operations; d) policy banking for EU priority projects' financing; and e) banking for advisory services. With these five different banking lines under one roof, the EIB enjoys full flexibility for its resource and cost allocation, able to pursue the most promising activity at any given time against the backdrop of ever-changing political, economic and market conditions. In the turbulent economic environment characterised by challenges, such as the globalization of the supply and demand sides of the real and the financial economies, climate change, and the economic crisis, the EIB's 2010 business model has proved itself robust, well crafted, pertinent and sufficient for the bank to not only survive but thrive in the pre-crisis, crisis and post-crisis periods, as shown in this analysis and as demonstrated in EIB's results. The EIB has consequently maintained its relevance by unceasingly supporting the ever-changing EU policies when it is called to succour, while being supported in this by the same political masters who demand its contribution. While upholding its support for regional development as well as economic and social cohesion in the EU, the EIB's activity has been shifting to a new priority of anti-crisis boosting economic activity, including human capital development, innovation, competitiveness and SMEs, as well as climate change mitigation. At the end of 2019, climate change mitigation was touted as the EIB's prime future priority when it pivoted to become the first international climate bank in support of the European Green Deal. In 2020, its new tasks will include supporting post-pandemic economic recovery and InvestEU, which constitute a challenge for EIB's activity consistency in its endeavours to fulfil different mandates, of which some have contradictory objectives. Further research on EIB's 2020 business model could shed light on how the EIB will align with these activities.

\section{Conclusion}

Since its establishment, the EIB has grown into a prominent EU institution with global clout. Its development and importance in European policy implementation, as well as its formation (Liebe \& Howarth, 2019; Mertens \& Thiemann, 2019) have accelerated in the last ten years. During this period, the EIB has been called to bolster the European economy during the global crisis by acting in a countercyclical mode and to support its recovery thereafter. To gain increased leverage, its activity has soared in volume, enlarging its sector reach, expanding into advisory services and diversifying qualitatively to cater to higher-risk projects. The EIB's business model has proven itself flexible, allowing inorganic and organic growth, while remaining solid in a turbulent economic environment. This is mainly due to the EIB's institutional nature and, in particular, to its strong shareholder support, its affinity with the Commission and the ECB and its pairing with peers and the banking sector. The EIB's institutional nature allows the bank to adapt its activity to EU calls, while its bank side is retrofitted by the EU to alleviate possible risks. Although there are changes in EIB's postBrexit statute in 2020, foreseeing, "along with the financial measures, a number of governance changes are planned" (EIB 2019b, p. 4), the above schema is expected to extend into the future. InvestEU, the Green Deal and the EU's response to the pandemic aim to deepen the blending of resources and the ties between the EIB and its sister institution, the Commission, in a "concept of an integrated partnership," as stated by the EIB's president (EIB 2019b, p. 12). 
Figure 1 The European Investment Bank 1999 business model

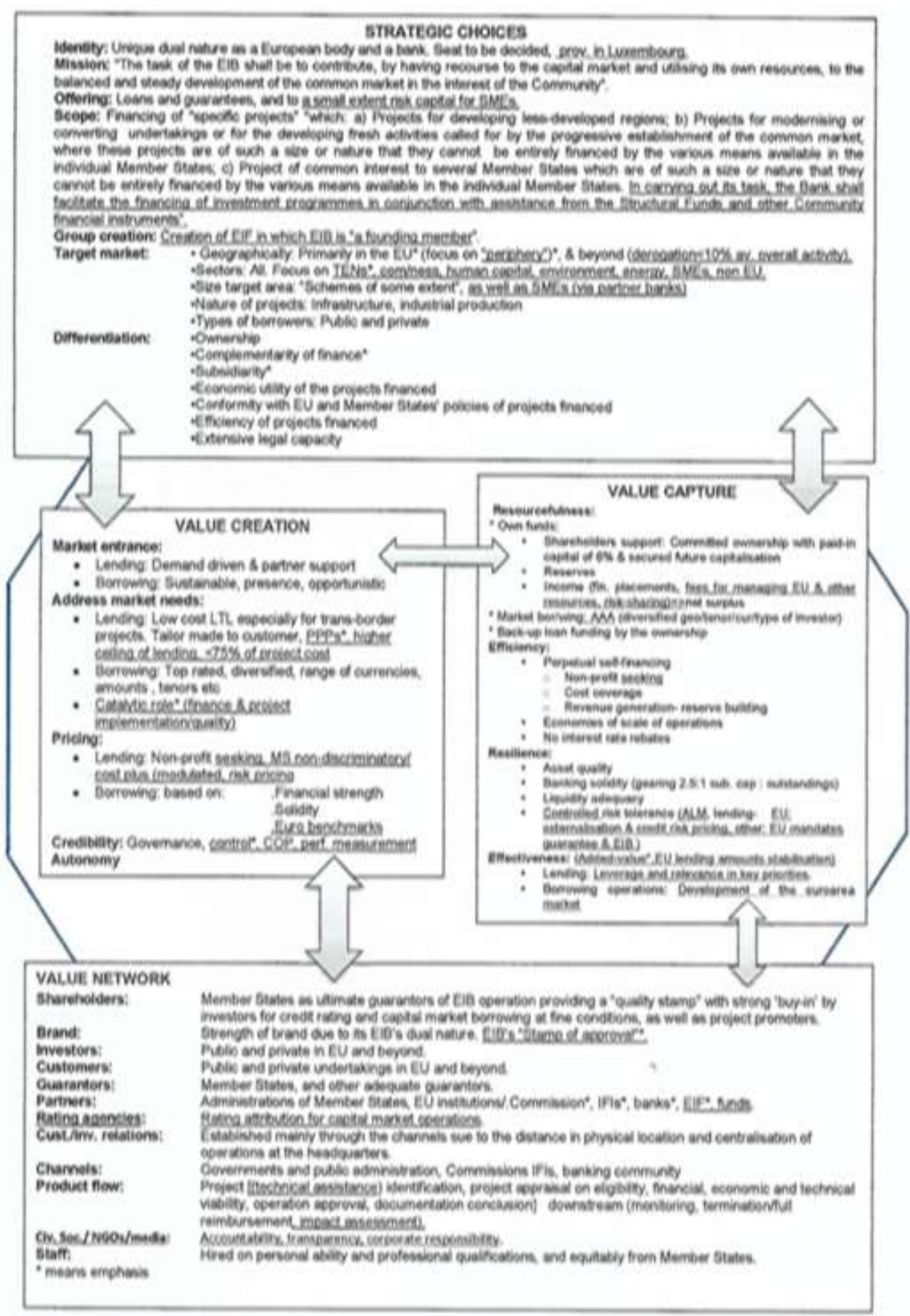

Source: Author's illustration 
Figure 2 The European Investment Bank 2010 business model

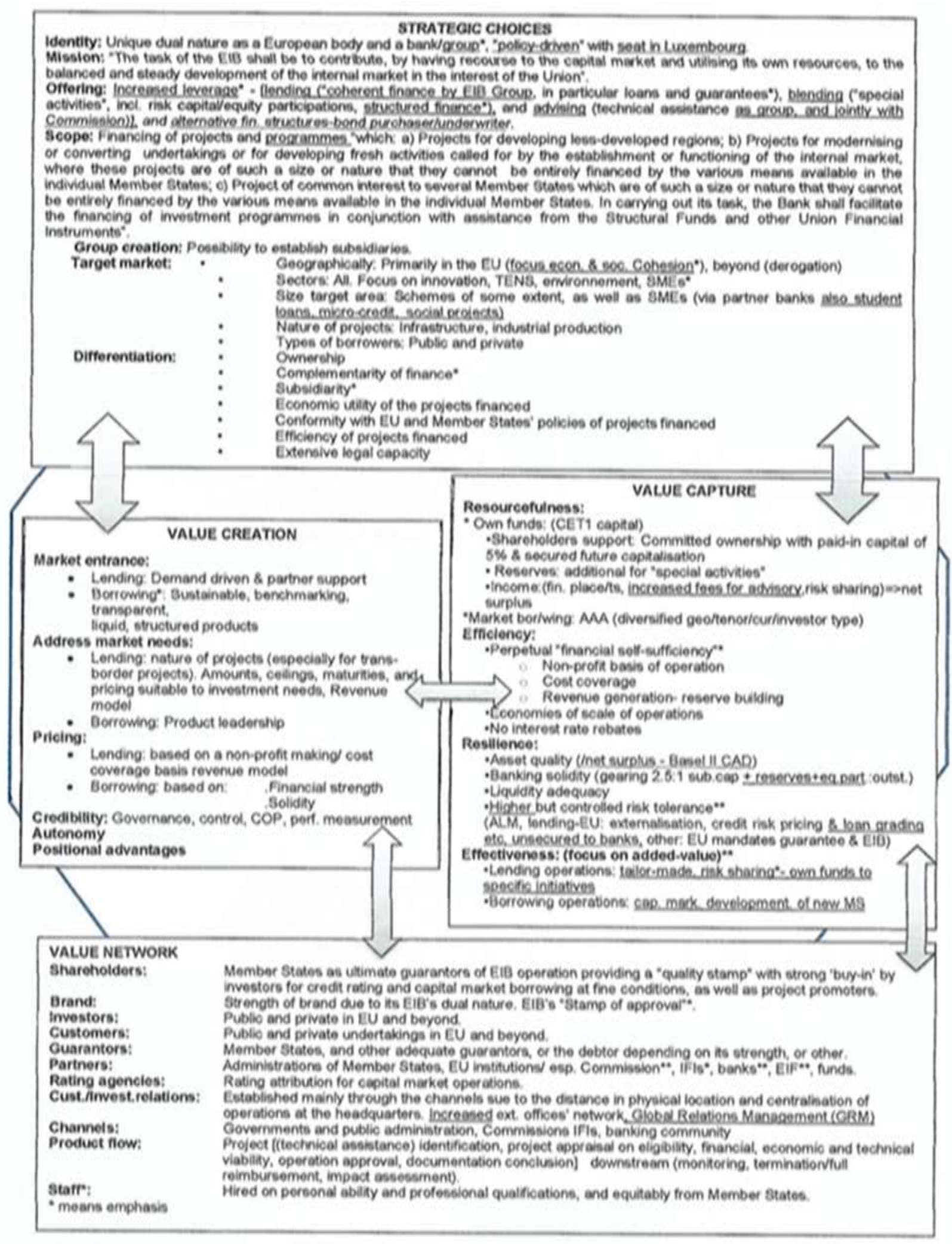

Source: Author's illustration 


\section{References}

Anghel, M., G., Anghelache, C., Dumitrescu, D. \& Ursache, A. 2016. 'The European initiative for small and medium enterprises', Revista Româna de Statistica-Supliment, nr 6.

Cavalcante, S., Kesting, P. \& Ulhoi, J. 2011. 'Business model dynamics and innovation: (re)establishing the missing linkages', Management decision Vol. 49 No.8, pp. 1327-1342.

Camdessus, M. 2010. 'Report and recommendations of the Steering Committee of "wise persons”', European Investment Bank's external mandate 2007-2013. Mid-Term Review.

Clifton, J., Diaz-Fuentes, D. \& Gómez, A.L. 2018. The European Investment Bank: Development, Integration, Investment? 'Journal of Common Market Studies', Vol. 56, no. 4, pp. 733-750.

Clifton, J., Diaz-Fuentes, D., \& Revuelta, J. 2014. Financing utilities: How the role of the European Investment Bank shifted from regional development to making markets, Utilities Policy, 29, pp. 63-71.

Edward, D. A. O. \& Lane, R. 2013. Edward and Lane on European Union Law. Edward Elgar Publishing.

European Investment Bank (EIB) 2019. 'Agreement on InvestEU confirms EIB Group as central partner for new EU investment programme in 2021-2027', press release, 21 March 2019, viewed 24.03.2019, https://www.eib.org/en/infocentre/press/releases/all/2019/2019081-agreement-on-investeu-confirms-eib-group-as-central-partner-for-new-eu-investmentprogramme-in-2021-2027.htm.

European Investment Bank (EIB) 2019. Hoyer, W. 'Speech at the Annual Press Conference', Brussels, 29 January 2019, viewed 29.01.2019, https://www.eib.org/attachments/general/events/annual-press-conference-2019-wernerhoyer-speech.pdf.

European Investment Bank (EIB) 2019. 'EU bank steps up efforts to fight climate change and foster innovation', press release, 29 January 2019, viewed 29.01.2019, https://www.eib.org/en/infocentre/press/releases/all/2019/2019-028-eu-bank-steps-upefforts-to-fight-climate-change-and-foster-innovation.htm.

European Investment Bank (EIB). 2017. Risk Management Disclosure.

European Investment Bank (EIB). 2016. Risk Management Disclosure.

European Investment Bank (EIB). 2011. Activity Report.

European Investment Bank (EIB). 2010. Activity Report.

European Investment Bank (EIB). 2006. Activity Report.

European Investment Bank (EIB). 1988. Annual Report.

European Investment Bank (EIB). 1999. Statute.

Fedele, A., Mantovani, A. \& Liucci, F. 2010. 'Credit availability in the crisis: which role for the European Investment Bank Group? University of Bologna, Department of Economic Science, Quaderni-Working Paper DSE No. 699.

Johnson, M. W., Christensen, C. M., \& Kagermann, H. 2008. 'Reinventing your business model', Harvard Business Review, December 2008, pp. 1-10.

Kavvadia, H., 2020. 'The European Investment Bank and the Asian Infrastructure Investment Bank: Incumbents and challengers in the field of regional development banking', in Clifton, J. Díaz Fuentes, D, Howarth, D \& Gómez, A. L. (eds) (upcoming) Regional 
Development Banks: Path dependence and institutional innovation in a shifting world economy, Oxford University Press.

Kavvadia, H. 2018. 'Small words, big changes', presentation at the WEHC Boston: 010206 - International Financial Institutions: Multilateral Investment and Development Banks since the Second World War, 1 August 2018.

Lewenhak, S. 1982. The role of the European Investment Bank, Routledge Library Editions: Banking \& Finance, Vol. 20, Routledge, New York.

Liebe, M. \& Howarth, D. 2019. ' The European Investment Bank as Policy Entrepreneur and the Promotion of Public-Private Partnerships', New Political Economy, 5 March 2019. doi: 10.1080/13563467.2019.1586862.

Lindblom, C. 1959. 'The science of muddling through', Public Administration Review, Vol. 19, pp. 79-88.

Marzinotto, B. 2011. 'A European fund for economic revival in crisis countries', Bruegel Policy Contribution, no. 2011/01, Bruegel, Brussels.

Mertens, D. \& Thiemann, M. 2019. 'The politicisation of the European Investment Bank? Managing hybritity and resource dependence in the European economic governance', paper presented at the Conference Analysing the European Investment Bank: Interdisciplinary approaches to understanding the past, present and future of the world's biggest lender, University of Luxembourg, 10-11 July 2019.

Official Journal of the European Union (OJEU). 2016. Consolidated versions of the Treaty on the European Union and the Treaty on the Functioning of the European Union . 2016/C 202/01. Vol. 59. 7 June 2016.

Osterwalder, A. 2004. The business model ontology. A proposition in a design science approach. Ecole des Hautes Etudes Commerciales de l' Université de Lausanne. Thèse de Doctorat.

Pistoia, E. 2014. 'Non-financial concerns in the lending policy of the European Investment Bank in context', in P. Acconci, M. Valenti, \& A. De Luca (authors) \& G. Sacerdoti (ed.), General Interests of Host States in International Investment Law (Cambridge International Trade and Economic Law, pp. 325-354). Cambridge: Cambridge University Press. doi:10.1017/CBO9781107279360.018.

Shafer, S. M., Smith, H., J., Linder, J., C. 2005. 'The power of business models', Business Horizons Vol. 48, pp. 199-207.

Szymczak, P. 2010. 'European Investment Bank: Supporting European objectives in Eastern Europe, Southern Caucasus and Russia', Eastern Partnership: Strategy for 2011 and Beyond - PISM International Conference. Lublin.

Zott, C., Amit, R. \& Massa, L. 2011. 'The business model: recent developments and future research', Journal of Management, DOI: 10.1177/0149206311406265.

\section{About the author}

Dr Helen Kavvadia is Visiting Research Associate, at the University of Luxembourg-IPS, teaching Europe and Global Economic Diplomacy, for the Master in European Governance. Prior to this, she was a Senior Adviser at the Communications Department of the European Investment Bank (EIB). She holds a PhD in Economics and Political Science from the Panteion University in Athens. Her research interest focuses on economic diplomacy, including Official Development Aid (ODA), International Financial Institutions (IFIs) and 
Croatian Regional Development Journal | Vol. 1 No. 1 | 2020

Foreign Direct Investment (FDI). The author can be contacted at helen.kavvadia@ext.uni.lu. 